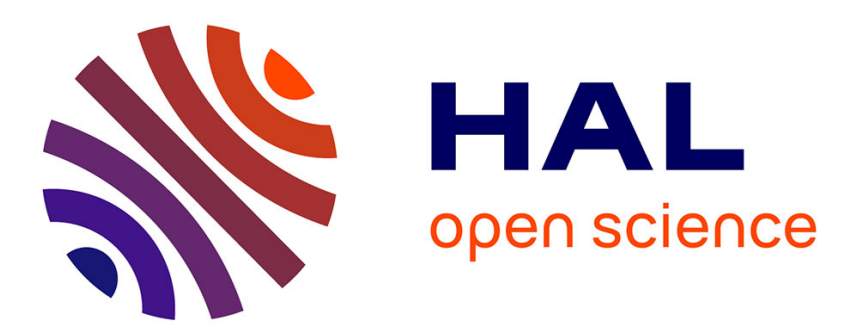

\title{
Women's Epistolary Cinema. Exploring Female Alterities: Epistolary Films and Epistolary Essay Films
}

\author{
Lourdes Monterrubio Ibáñez
}

\section{To cite this version:}

Lourdes Monterrubio Ibáñez. Women's Epistolary Cinema. Exploring Female Alterities: Epistolary Films and Epistolary Essay Films. Feminist Media Studies, In press, pp.1 - 20. 10.1080/14680777.2021.1900313 . hal-03161564v2

\section{HAL Id: hal-03161564 \\ https://hal.science/hal-03161564v2}

Submitted on 27 Mar 2021 (v2), last revised 6 Dec 2022 (v5)

HAL is a multi-disciplinary open access archive for the deposit and dissemination of scientific research documents, whether they are published or not. The documents may come from teaching and research institutions in France or abroad, or from public or private research centers.
L'archive ouverte pluridisciplinaire HAL, est destinée au dépôt et à la diffusion de documents scientifiques de niveau recherche, publiés ou non, émanant des établissements d'enseignement et de recherche français ou étrangers, des laboratoires publics ou privés. 
This is an Original Manuscript of an article published by Taylor \& Francis in Feminist Media Studies on the $27^{\text {th }}$ March 2021, available at

https://www.tandfonline.com/doi/full/10.1080/14680777.2021.1900313

\title{
Women's Epistolary Cinema. Exploring Female Alterities: Epistolary Films and Epistolary Essay Films
}

\author{
Lourdes Monterrubio Ibáñez \\ Complutense University of Madrid \\ loumonte@ucm.es \\ ORCID: $\underline{0000-0003-0566-3666}$
}

This article aims to carry out an analysis of female authorship in the materialisations of contemporary epistolary cinema, focusing on epistolary films and epistolary essay films. The works of various filmmakers are essential to understand the evolution of this enunciation device and the exploration of female alterities materialised through it. Women filmmakers epistolary practices delve into the exploration of intimate space, authorial vindication, epistolary materiality, intersubjectivity and cinematic thinking to create diverse experiences of female alterity, developing this postmodern paradigm inherent to epistolary device. Since Chantal Akerman started the practice of the epistolary film with News from Home (1977), other women filmmakers have developed this cinematic form. The reading of a personal correspondence allows to explore female intimate alterities Measures of Distance (1988), Punto impropio (2015), A Minha Avó Trelotótó (2018). Besides, the epistolary film is fictionalised, displacing it to the intellectual space-From Hetty to Nancy (1997), Endless Dreams and Water Between (2009). Other's real correspondence is also instrumentalised to create their recreations and representations, vindicating female alterities both socially and personally -Letter \#69 (2016), The Dreamed Ones (2016). Finally, women filmmakers addressed the cinematic form of the essay film -Letters from Panduranga (2015), Correspôndencias (2016).

Keywords: women's cinema; epistolary film; essay film; alterity; cinematic enunciation 


\section{Introduction}

Women's epistolary cinema starts from three key epistolary works by three French filmmakers who, in the space of three years, offer three crucial works in the evolution of this enunciative device, and use it to materialise a female discourse: L'une chante, l'autre pas (1977, Agnès Varda) through the correspondence inside a narrative in which the filmmaker places herself as an intermediary narrator; Aurélia Steiner (1979, Marguerite Duras) using the letter-film in which the author becomes a fictional performer; News from Home (1977, Chantal Akerman) materialising a new form, the epistolary film, in which the filmmaker is the documentary protagonist. The three films are the starting point of a deep relationship between female authorship and an epistolary cinema which proliferates in contemporary space (Monterrubio 2019) through its different possibilities: letter-film, filmic correspondence, epistolary film and epistolary essay film.

With the advent of postmodernity, the concept of alterity becomes hegemonic, as many authors have analysed -Kristeva (1988), Bauman (1991), Augé (1992), among others. Paul Ricœur, for his part, establishes three modalities: "proper alterity, alterity of the other, alterity of conscience" $(1990,410)$, through which he describes and studies the complexity of this "ontology of alterity" (373); the dialectics between ipseity and otherness. The idiosyncrasy of the epistolary device lies in the interrelationship of these three modalities, becoming an ideal tool in the cinematic field to explore this experience, and materialising this paradigm shift in filmic creation. Besides intimacy, self-expression, the border between private and public spheres and, of course, the digital revolution as reasons for the proliferation of epistolary enunciation in contemporary cinema, I argue that it is the necessity to explore the alterity experience the nuclear reason of the proliferation of the epistolary device and also of the multiplicity of its forms, since it becomes a powerful ontological instrument to this purpose. The three films mentioned 
express, reflect and vindicate female subjectivity thanks to the experience of alterity and its three modalities, and other women filmmakers has been able to continue its exploration. This article will focus in the evolution of the epistolary film and the epistolary essay film that starts with News from Home.

The first consequence of the prominence of alterity regarding the epistolary device is the relevance gained by the epistolary addressee, which causes the evolution from the letter-film to the epistolary film. While the letter-film of modern cinema was focused on the subjective expression of the addresser, the importance of the alterity makes the epistolary act include the presence of the addressee, as Letter to Jane (Godard and Gorin, 1972) already advanced. First, the letter-film is converted into an epistolary film by replacing the writing of a single letter with the reading of a set of them. A film is essential to enable this evolution: Chantal Akerman's News from Home (1977) becomes the first epistolary film, by constructing its enunciation through Akerman's reading of the letters from her mother. Thus, the epistolary film finally reaches its literary model and the film is enunciated through a series of letters (Monterrubio 2018, 284-292). Some years later, Sans soleil (Marker, 1983) transforms the epistolary writing of Lettre de Sibérie (Marker, 1958) into the reading that the addressee (and unknown woman) makes of Kasna's missives. Akerman's film, besides starting the exploration of the epistolary film, developed from her real and intimate correspondence, delves into the generational gap between mother and daughter and provides an artistic experience of great relevance to feminist analysis (Longfellow 1989; Margules 1996; Barker 2003; McFadden 2014). The constant concern for the daughter and the insistent request for letters become a kind of family ambient sound, which is not paid attention: 'a mother's murmur that comes from far away, from the mother tongue precisely, to worry about an absent body [...] This voice of a mother in search of her lost daughter disperses, weakens, persists in New York' 
(Bulher and Laplace 1977, 54). Thus, this epistolary material is related to the Lacanian notion of llanguage, as indicated by Daniéle Dubroux (1977), defined as the structure of the unconscious that goes beyond the communicative notion of language to include the specific characteristics of each individual, in relation to family learning and its idiosyncrasies (Lacan 1998, 139). The epistolary writing represents the preservation of memory for the mother and, therefore, of the maternal-filial bond: 'Do not forget us. Write', which is close to the pathological identification: 'I live at the rhythm of your letters.' The film offers a reflection on the abysses that surround the experience of maternal-filial alterity: 'News from Home is a film about emptiness, anguish... A deep hiatus, something impassable, it exists between these two worlds, New York and Brussels family life' (Maupin 1977, 109). I will analyse how this notion about family idiosyncrasies and female subjectivity and alterity is explored by different filmmakers in different and fruitful ways following the road open by Akerman.

This article addresses the most notable works made by women filmmakers classified into four practices: epistolary films that use the filmmakers' real and personal correspondence; those constructed as epistolary fictionalisations based on documentary image; the interpretation and/or recreation of other people correspondence; and finally, the materialisation of epistolary essay films. All of them explore the three modalities of alterity already mentioned, creating a common, shared space that connect them and overcome their different cultural and mediatic contexts, providing a female cinematic experience of alterity and the power of this filmic practice.

\section{Intimate alterities}

Ten years after Akerman's film, Mona Hatoum continues this epistolary experience in Measures of Distance (1988), using the same crucial element, the letters sent by her 
mother. In this case, those caused by Hatoum's getting stranded in London because of the Lebanese civil war. While Akerman used correspondence to deepen the generation gap between mother and daughter, Hatoum instead explores the depth of the mother-daughter bond despite the distance. Furthermore, Hatoum introduces a new element: the materiality of the written letter.

The short film begins with a succession by crossfading of five detail shots, in which we discern a body, and to which the image of epistolary writing, the handwriting weave of Arabic on the paper, is superimposed. From the sound image the conversation between the two women arises. It provides an image of the emotional bond, of the intimacy between mother and daughter, sifted by the distance evidenced by the letters, as we realise later. Then, Hatoum's voiceover emerges, beginning the reading of a letter from her mother, but translated into English: 'My dear Mona. The apple of my eyes. How I miss you and long to feast my eyes on your beautiful face that brightens up my days.' In this way, the specific stratification of audiovisual epistolary writing materialises, in which both images express distance: between the photographic images of the meeting and that of the letter; between the sound of the conversation and that of Hatoum's reading in the language of exile. Like Akerman, Hatoum uses the mother's monodic epistolarity: five missives that start with "My dear Mona" and through which the addresser is going to express her emotions regarding the daughter's exile and also her reflections on the women's reality in her culture. We listen to the animated talk of mother and daughter in the background, without their dialogue being translated, configuring an emotional landscape of the bond. The Lacanian llanguage referred to in Akerman's film takes on an opposite meaning here, a kind of rumor of the home as a refuge.

The first letter reveals the origin of the images we observe: the nude portrait of the mother's body from a photo shoot in the absence of the father, and from whom it must 
be hidden, thus generating the epistolary film in the space of transgression. As Hamid Naficy analyses in his indispensable work about the bond between filmic epistolarity and exile: 'Hatoum's transgression is in line with what Derrida has called the "postcard structure" itself, one that raises questions about what is public or private, inside or outside, real or fictional' $(2001,120)$. Besides, epistolary materiality is then associated with the haptic camera defined by Laura Marks:

It is the skin of the mother, as well as the indexical trace of her voice on tape, that gradually activate the sense of her mother's presence as well as the painful finality of her absence $[\ldots]$ a muffling quality that seems to want to fill in the gap by appealing to the memory of touch $(2000,55-56)$.

Faced with the fragmentation of the images during the first two letters, the third offers the complete portrait of the mother, while her epistolary words address her reflections on sexuality (Figure 1). Thus, the epistolary alterity, the maternal figure, is revealed thanks to the filmic device. The fourth missive continues with the camera moving away from the mother's body, of which we contemplate a general shot that is then superimposed on another detail shot before disappearing, thus materialising again the idea of the epistolary stratification made possible by the audiovisual device. The epistolary film, caused by exile, generates a gradual identity portrait of maternal alterity that also faces the reality of absence, since reading the last letter on the black screen and without the sound image of the conversation. This absence of visual image also shows the possibilities of the audiovisual letter compared to the literary one. Not only its visual materialisation but also its possibilities of stratification, both in the visual image and in the sound image.

Figure 1. Measures of Distance (1988. Mona Hatoum) Courtesy of the filmmaker. 
Albertina Carri moves the epistolary film to the video installation space with Punto impropio (2015), which is constructed from the letters that the filmmaker's mother, disappeared under the Argentine military dictatorship, writes to her three daughters during the months of captivity, when Carri was four years old. Three zenithal projections are shown in a dark room: 'Two horizontal projections and a square projection placed in the middle of the other two [...] The two rectangular projections (horizontal) form my mother's name ANA MARÍA, the square projection is a point in the middle of her two names' (Carri 2016, 165). That point, a circular screen, gives way to the projection of images of the letters through a microscope view, turning them into an unrecognisable abstract geography of the surface of the paper and the ink inscribed on it, where the handwriting disappears to become strangehood. On these images, Carri's voice-over reads the mother's letters, pronouncing the dots, the commas, the line changes, as if it were a school dictation. Thus, through the two epistolary forms (visual image and sound image) the experience of trauma materialises, the vertigo of the impossibility of apprehending a maternal message at the age of four. The need of the years passing to be able to decipher it makes its reading an already apocryphal text, showing the abyss of absence of almost forty years. The texts are divided into three blocks, separated by two brief inserts from her previous autofictional film, Los rubios (2003): the narration that the filmmaker's character (played by Analía Couceyro) made of the parent's kidnapping. In other words, the epistolary film shows the need to return to her own experience, stripped of the autofictional device of the previous work. From her own memory enunciated by an actress, and in which the correspondence did not appear, to the mother's letters read by the filmmaker. While Los Rubios distanced itself through autofiction, Punto impropio approaches through the epistolary experience until abstracting it. Furthermore, both images are manipulated to cause a sensation of saturation, of sensory dizziness. The 
microscopic visual image is focused and unfocused, moves across the surface of the paper and rotates, as if it were the entire screen that was spinning, also changing its sense, contributing to the perception of the impossibility of apprehension. In addition to the filmmaker's voice, the sound image instrumentalises a musical melody that appears and disappears, and that at different times becomes a disruptive element, another ingredient of sensory discomfort. This modulation on which the work is built is revealed in minute 10 of its footage. During the reading of the fourth letter, addressed to the three daughters, the music disappears first, and the voice weakens, becomes a kind of murmur that turns it into a new materialisation of Lacan's language, regarding and revealing once again the identity-alterity relevance of the mother-daughter bond. Only when the voice becomes a faint echo the handwriting reveals itself in image; the microscopic magnification disappears and the mother's writing is accessible to the human eye, but upside down; never completely accessible (Figure 2). This decalage between the intelligibility of the epistolary voice and the epistolary image is a lucid metaphor for the trauma that this correspondence contains. From that moment on, the handwriting and the voice get closer and farther throughout the work, evidencing the daughter's determination, through all those years, for decoding the mother's messages. That process could finally be successful when intelligible handwriting and voice coincide during the most terrifying content: 'If the letters reach someone who wants to harm us, they kill us. And this is literal, they shoot us, so go find them personally.'

Figure 2. Punto impropio (2015, Albertina Carri). Courtesy of the filmmaker.

The epistolary content, the mother's constant attempt to care her daughters in the distance, covers all possible spaces, from the purely biological to the emotional and intellectual. The need to educate them becomes Ana María Caruso's literary work, also as a feminist vindication: 
Those letters are the book that Ana María Caruso could not write. Because she was a very young mother, because she was the wife of a promising intellectual, because she was murdered at just 36 years old. Punto impropio runs through my mother's non-work and the power that the treatise Ana María wrote in epistolary format -that non-book- has on my voice (Carri 2015, 15).

It is possible to experience this female alterity of the absent mother through the film also due to the author's vital reality, who is older than her mother when she was murdered and who also already knows the experience of motherhood. A vital moment where personal experience is vindicated with greater force as a social and political experience: 'Letters function as a place to always return to in the face of horror, like a trace [...] I think there is an immense political tool there' (Altilio 2020).

While Akerman and Hatoum explore the maternal alterity, Catarina Ruivo addresses to her grandmother Julia in O Minha Avó Trelotótó (2018). The work is built from the spaces inhabited by the protagonist, which now trace her absence. The different characters of her daily life reproduce the scenes and actions they shared with her in front of the present absent space she occupied. This anonymous absence will be endowed with identity through her correspondence. Julia herself, in a past audiovisual document, goes through a family photo album that becomes the structural axis of the film, stating her different life stages. Born in Luso, a pharmacist as profession, she married Zé Antonio and they moved to Mozambique in 1946. After four children, her job as a teacher and different movements around the country (Chobela, Vilanculos, Mutuali), her husband died in 1957 . This is the period mainly narrated by the missives, which are completed with the account of the mourning, the new partner, Alexandre, and finally the correspondence with Ruivo herself. Thus, the biographical narrative is delegated in her correspondence, in the letters written by Julia, mainly, but also some addressed to her or belonging to other characters. Julia's missives, enunciated through the voice-over of Rita 
Durão, who plays vocally the grandmother, will generate various epistolary expressions, one of them of particular relevance due to its innovation.

The first two letters, from Zé Antonio (played vocally by António Pedro Figueiredo) to Julia when they were still dating, generate a first device: the first epistolary text is enunciated on a $\mathrm{B} / \mathrm{W}$ photograph of both at that time; the second gives way to the moving image of that same place in the present. Next, the third text already offers the new device: in a present color image, a B/W silhouette of Julia is inserted, as a cutout, belonging to a past image. In this way, the filmmaker continues to experiment with the expressive possibilities of absence. The total absence represented in the present time is now followed by this new figuration between the present space and the past image. It is necessary to point out the choice of the screen format: the $4: 3$ used homogenises the whole of the work (only some moving images of Julia keep their original format) and emphasises the idea of the mentioned collage-images as a sort of audiovisual postcards that remediate this epistolary object turning it into an artistic expression. It is necessary to note the relationship of this new device with Agnès Varda's installation La Grande Carte postale ou Souvenir de Noirmoutier (2006), also generated from the idea of collage, proving also the evolution of the device from L'une chante, l'autre pas (Bluher 2019). This innovative epistolary device is also used as an expressive element to relate the death of the husband. His silhouette, in the middle of the road, is moved away by a travelling out, unique in the entire film, without any text. Among Ruivo's collage-images, three of them change the current moving image for pictorial images. In the most relevant of them, a photograph of Julia is inserted in Edward Hopper's Compartment C, Car 293 (1938) (Figure 3), while we listen to the letter that Alberto, her assistant and friend in the Mozambique years, writes to her on the first anniversary of her husband's death. Julia, as 
we will see in the outcome of the film, thus achieves the immortality she demands to her granddaughter.

The bond shown with her mother: 'you can be sure of this deep truth: I love you and I understand you and without you there is no root to my life', and later with her daughter: 'I feel useless not being able to help my Gracinha. [...] They are happy or unhappy far away from us... I wish I could give her the moon!,' culminates with her relationship with the filmmaker. The collage-images, in this case that of Julia on the beach give way to the moving images of Julia recorded by Ruivo, images from the personal archive that now acquires the status of film creation, thus fulfilling the grandmother's desire, enunciated in a truly beautiful letter that shows the bond the film generates: 'And you are not here to revive me, to make me feel the miracle of resurrection that you always brought me [...] Come on... Don't abandon me! I need you as much as food needs salt.' Once again, the epistolary creation of women filmmakers generates new expressions of this device in order to deepen the experience of female alterity, in this case, the grandmother-granddaughter relationship.

Figure 3. O Minha Avó Trelotótó (2018, Catarina Ruivo). Courtesy of the filmmaker.

\section{Fictionalisation of the epistolary device}

The epistolary film also evolves towards a fictionalisation that is generated from the documentary image and different forms of textual inscription. In From Hetty to Nancy (1997) Deborah Stratman experiments with different possibilities of hybridisation between the documentary image of Iceland and diverse texts, the main one being an epistolary literary work by Louis McNeice, 'Hetty to Nancy', belonging to Letters from Iceland (1937), written in collaboration with W.H. Auden during their trip through the country in 1936. In this way, the film is built from the hybridisation of the $16 \mathrm{~mm}$ 
documentary image and the letters Hetty writes to Nancy, also during her tour of the island. Away from romantic travel letters, McNeice creates a humorous and ironic account of the journey of four schoolgirls accompanied by Mrs Greenhalge, the expedition leader, and Hetty and Maisie, two young university girls. Stratman selects various fragments of the text, maintaining its structure -the diaristic letters of the ten days of travel- that are enunciated by a female voice-over that we identify with Hetty, due to her vocal acting of the letters. In this way, a first confrontation occurs between the powerful images of the Icelandic nature (Figure 4) and the mundane account of the anecdotes of this particular expedition: from the dire state of Hetty and Masie's tent, the comical clothing of the group or the criticism of young women, to the tedium produced by the visited landscape:

In the centre of Iceland there are only three kinds of scenery — Stones, More Stones, and All Stone. The third type predominated today. The stones are the wrong size, the wrong shape, the wrong colour, and too many of them. They are not big enough to impress and not small enough to negotiate. Absolutely unpicturesque and absolutely non-utilitarian [...] It's certainly hard to think how a country gets in a mess like this.

Figure 4. From Hetty to Nancy (1997, Deborah Stratman). Courtesy of the filmmaker.

To this epistolary structure, Stratman adds other materials that deepen experimentation on the reinterpretation of the documentary image in relation to the materials next to which it is shown. Alternated with the epistolary fragments, the film shows six texts inscribed on the screen that go through it as a roller and two other voiceover enunciations subtitled on the image. These are texts from books on travels and expeditions to the island in the $18^{\text {th }}$ and $19^{\text {th }}$ centuries (Jón Porláksson 1727; Eggert Ólafsson \& Bjarni Pálsson 1752-1757; Willliam Jackson Hooker 1809) that offer different facts and information about Iceland: from those related to geography -attempts 
to climb the Langjökull glacier, the eruption of Öræfajökull in 1727, icebergs- or fauna -types of wolves-, to the historical ones -the Algerian pirates in the $17^{\text {th }}$ century or the fire of a ship. The documentary image also mixes images of the country powerful geography with others dedicated to its most mundane day-to-day life: the daily care of a flock of sheep or the loading and unloading of boats. All these elements materialise Hetty's gaze, that of a comic, ironic and satirical female subjectivity that once again abandons stereotypes to vindicate its uniqueness. Thus, the film continues exploring some of the epistolary elements used in Lettre de Sibérie through its fictionalisation: the irony of subjective perception and the questioning of objectivity associated to observational documentary.

In Endless Dreams and Water Between (2009), Renée Green generates a fictional epistolary narrative through the voice-overs of four characters, while the visual image is again of documentary nature. The fictional character of Aria Phoenix, who lives in Mallorca, sends a written letter to three women to propose them an epistolary exchange which should become a space for thinking and reflection on the texts they read, and based on a circumstance common to all of them: to inhabit in an island or peninsula. The idea arises from a vivid dream in which Aria founds The September Institute, a space dedicated to this insular thinking: 'thinking from the islands we inhabit.' Its three addressees: Raya (San Francisco), Lyn (Manhattan) and Mar (Mallorca) respond to the proposal with their first writing letter exercise. In this way, the film is built on six epistolary texts: Aria's proposal and a second letter, the responses of the three recipients and Aria's response to them. Therefore, fictional characters belong exclusively to the sound image, while the visual image shows water landscapes (Image 5), the islands where they live, and different archive images inserted in relation to the epistolary contents. Thus, the film does not intend to create an audiovisual epistolary enunciation but, on the 
contrary, it becomes a reflection on literary epistolary writing as a source of thinking and, more importantly, as an engine of intersubjectivity among these four female characters:

Ideally, I would like us to explore writing letters. This is something that has become nearly extinct and I'd like to attempt reviving this art of writing actual letters [...] These letters can be sent via e-mail, although I'd like to experiment with sending them by post, so that it is possible to have something tangible we have touched.

Figure 5. Endless Dreams and Water Between (2009, Renée Green). Courtesy of the filmmaker, FAM, and Video Data Bank.

Therefore, the visual image represents a second level of the film, a sort of consequence of the insular thinking produced by the letters, offering a visual space-endless dream and water between- of reflection about the letters read in the sound image: "The water between islands -the sea-can be understood as a kind of screen, a surface upon which meanings temporarily coalesce" (Gray 2010, 27). This insular thinking, which takes the reflections of Gilles Deleuze in Desert islands and Others Texts, 1953-1974, has as its epicenter the protagonists' readings of Georges Sand's Winter in Mallorca (1841) and her endless correspondence, from which Lettres d'un voyageur (1837) collects a sample. This practice of instrumentalising the epistolary activity of female artists, again influencing the exploration of female alterity, will be repeated in two other later works. The film thus draws a female intellectual intersubjectivity that is also supported by the reference to Laura Riding's literary creation. After the first epistolary delivery of all of them, Aria is then in a position to establish the postulates of the September Institute and its future activity: "3. Sending transmissions from dispersed islands, linking worlds, time, and space. 4.We continue the ongoing movement of combination people." As Lisa Le Fleuvre analyses, the film 'interrogates how imagination and negotiation of our place in the world collide and corrupt, charging projections, fabulations, and dreams with the complexities of the present' $(2010,17)$. Therefore, the film, is not constructed as an essay 
film that produces cinematic thinking, but as an audiovisual space that favors the absorption of epistolary female intellectual intersubjectivity and encourages the spectator reflection. In this regard, it is necessary to point out that film belongs to a larger museum installation developing some aspects of what the film proposes, expanding the possibilities of this spectator reflection.

\section{Representation and recreation of others' correspondence}

As advanced before, some filmmakers create the epistolary film starting from others' correspondence. Letter \#69 (2016, Hsin-I Lin) is an epistolary short film created from the 68 letters that Shi Shui-huan, a 29-year-old woman, wrote from prison, during the 19 months that she was detained in Taipei as a victim of the Taiwanese White Terror, before being executed in the summer of 1956. The filmmaker then creates an epistolary film that aims to convey the silence and oblivion to which the victims of the regime were subjected. In this case, the 201 victims buried in the Liuzhangli Mass Grave, forgotten for decades. To do this, the epistolary texts are treated through a new and innovative procedure that delves into the possibilities of stratification of audiovisual epistolarity. First, the filmmaker's reading of the letters is reproduced in reverse, making its enunciation an act of denunciation about the silencing to which the victims were subjected: "the reverse playback of the director reading Shi Shui-Huan's letters, serving as an audible but incomprehensible discourse' (Boscarlo 2016). While Akerman instrumentalised the unintelligibility of the epistolary text as an expression of the intimate conflict, Lin uses it to denounce the historical trauma. Secondly, the epistolary texts are written on an analog film, shown on the screen, which is not intelligible either, this time as a metaphor for forgetfulness work produced by historical time. Finally, they are also transcribed on the current digital image, a space in which its reading is finally possible. The visual image, meanwhile, offers a kind of sensory recreation in relation to their content: 'The scene is 
set in an abandoned Japanese-style building in Taiwan and a prison scene in a human rights park' (Boscarlo 2016).

At the beginning of the film, the voices of different women, relatives of the protagonist, narrate her arrest through their voice-overs, while we listen to the sound of the film projection and the unintelligible enunciation of the letters. The visual image shows us the materiality of an analog film and the epistolary text, also illegible on it (Figure 6). This hybridisation of elements around the silencing of victims throughout history is confronted with the inserts in digital video, which extend throughout the entire work, and which show us the Liuzhangli graves, on whose image the names of the disappeared to which they belong are inscribed. Next, the arrest report, in October 1954, is also inscribed on the screen, on a very close-up of the eyes of one of the women, and then her hand treasuring and caressing an embroidery and a watch. With the title over the image, a constant hitting is now added to the sound image, which we discovered a few seconds later in the image: the manual boring of the analog film. The six letters transcribed on the screen (\# 1, \# 2, \# 3, \# 4, \# 5, \# 68) accompany the visual image that shows spaces of recreation of the imprisonment, giving prominence to everyday objects that appear in the epistolary content. The presence of a woman implies a vindication of historical memory and enables a sensory recreation, especially tactile, of what the addresser experienced: 'the personal history of the victims is construed in non-archival data' (Bocarlo 2016). The film advances then in the materiality already analysed in Hatoum's and Carri's films, now transferred to the recreation of the situation of enunciation. On the epistolary texts, the visual image oscillates between the interior of these recreation spaces and the exterior of the mass grave. After the third and fourth letters, two poems are introduced, copied by hand by the addresser herself. From the fifth missive it jumps to the last one, \# 68, since \# 69 was never written. On the black screen 
we only heard the sound of the execution that prevented its writing. After this epistolary enunciation of six letters and the irrealisation of $\# 69$, the sound image resumes its reverse reproduction, its intelligibility, a metaphor of oblivion. Like the prologue, the epilogue denounces the ostracism to which the mass grave was relegated: 'The Liuzhangli Graves lay here covered by grass, unclaimed, victims of political strife with no voice which to defend themselves.' Once again, it is the female subjectivity that is explored through the experience of alterity that the epistolary legacy provides, in this case associated with the vindication of historical memory.

Figure 6. Letter \#69 (2016, Hsin-I Lin), Courtesy of the filmmaker.

In The Dreamed Ones (Die Geträumten, 2016) Ruth Beckermann creates a new epistolary experience taking the correspondence between the writers Ingeborg Bachmann and Paul Celan and creating a minimal but enormously revealing plot of the epistolary experience: the sound recording of the correspondence, carried out by two characters/actors that the spectator will only meet through this epistolary representation, since they not just read the texts but they act them. More than seventy texts are selected, from the 196 letters of the correspondence published in 2008, covering the 20 years of relationship between the two writers, become a reading shared by two strangers who little by little discover their bonds with the texts. It will provoke in turn the dialogue, the need to express themselves about them. Thus, the film explores a recording session that becomes a sort of epistolary microcosm, following the chronological order of the correspondence, from their first meeting in Vienna in 1948 to Celan's last letter in 1967.

The film begins with the recitation of the first epistolary texts, through a shotcountershot of the close-ups of both characters. Thus, the variations between voice-in and voice off-field, between recitation and listening, between writing and reading, offer a first 
and subtle experience of the epistolary fact from which its different facets will be explored. The recording will be punctuated by brief breaks, up to seven, which will allow us to observe how the epistolary reading generates the evolution of the relationship of its performers; from the distance of the strangers to the proximity of the shared emotional experience through epistolary correspondence. After the first break, in which both characters go out to smoke, the correspondence continues as the listening that the characters make of their own performance of the following two texts. The epistolary experience is thus captured from different angles: the enunciation itself, the listening of the other; the listening of both outside the epistolary dialogue; and later the instrumentalisation of the epistolary text as a voice-over that accompanies the visual image of some of the following breaks, as if the correspondence between Bachmann and Celan absorbed its current situation of enunciation. The first voice-over enunciation, of Bachmann, shows both performers during the third break, separated, so that they then start a dialogue about the correspondence, in which they not only try to understand the decisions of the correspondents, in this case Bachmann's decision not to send a letter, but to imagine and project themselves into the situation described in the text. The experience of this epistolary performance/reading expands its space of influence. The possibilities of this epistolary enunciation continue to evolve and the correspondence gradually becomes dialogue. A letter from Celan is interrupted on several occasions by a Bachmann's sentence, which repeatedly asks about a verse of Celan's poem -'Cologne, Am Hof'giving also its title to the film: 'But are we only the dreamed ones?' The sentence synthetises Bachmann conflict regarding Celan's marriage and the filmmaker evidences her interest about the female side of the relationship, that will be explore until the end of the film. Bachmann's following letter is enunciated through the voice-over while the visual image shows him listening with headphones, showing again that crucial decalage 
between the epistolary production and its reading, also hybridising that reality of 1957 and the cinematic present. The epistolary texts are then reduced and their alternation make of them the dialogue, suggested before, that all correspondence yearns for. At the same time, the identification between correspondents and performers advances, evidencing the ability of epistolary writing to reveal the deepest spaces of identity and to allow identification. This progression concludes with Bachmann's last letter, while being ill. For the first and last time in the film the actress looks into the camera, which materialises a kind of feminist recognition of Bachmann's vital experience, who had to face patriarchy both in her creative activity as a writer and in her love relationship with Celan, as the letters reveal (Figure 7). Although the film includes both writings, it seems evident that, once again, that the female filmmakers carry out an exercise of sorority, choosing the point of view of the female character. Once the film concluded with the text on the screen that informs us of the deaths of both -Celan's suicide in 1970 and Bachmann's death in 1973 after a fire-, the filmmaker adds a short epilogue that confirms this idea, in which the actress reads a last text by Bachman, this one non-epistolary -belonging to Malina (1971)- and unrelated to the recording, about Celan's death: 'My life is over, for during transport, he drowned in the river. He was my life. I loved him more than my own life.'

Figure 7. The Dreamed Ones (2016. Ruth Beckermann). Courtesy of the filmmaker.

\section{The epistolary essay film}

The instrumentalisation of the epistolary device in the space of the essay film has been the latest practice addressed by women filmmakers. Only recently we find two works that not only immerse themselves in that practice, but whose results place themselves at the avant-garde of the epistolary essay film. 
Letters from Panduranga (2015) by Nguyen Trinh Thi is not only generated as a successor of Marker's epistolary essay film, but the filmmaker is able to continue its evolution, delving into the possibilities of the device as an enunciation form: 'It is this split and this in-betweenness that the epistolary narrative most distinctively has to offer to the essay film and its disjunctive practices' (Rascaroli 2017, 154). The link with Marker's epistolary work is made explicit when the film begins and ends with the same words that Lettre de Sibérie does. The film thus encompasses the evolution that occurs between the latter and Sans Soleil -the latter generates a problematisation of epistolary diegesis that evidences the presence of the essayist as an extradiegetic entity (Monterrubio 2018, 293-308)- as the filmmaker confirms: 'I was strongly influenced by Chris Marker and his essay films, especially Sans Soleil. I borrowed from Marker his strategies and structures' (Rascaroli et al. 2019, 24). Nguyen continues Marker's work to advance its possibilities, creating an epistolary dialogue between two anonymous characters that is configured as a split identity-alterity of the essayist, as the author explains: 'They are both mostly myself, or to be more precise my different selves, my selves of different times and spaces' (Rascaroli 2017, 154). Therefore, internal dialogue becomes epistolary dialogue that allows an identity dialectics that materialises in an exemplary way the postmodern conception of alterity and its gender dimension. The film begins as an epistolary film composed of the letters exchanged between a woman and a man, both developing an audiovisual work in different territories of Vietnam, enunciated through their voice-overs, hers belonging to Nguyen herself. Thus, the film would materialise a completely coherent diegetic epistolary narrative. The first letters are developed in this diegetic space, until reaching the sixth, third of the male character, from which a new enunciative element emerges: the split screen. It shows us, first of all, a dance scene. Both images duplicate the same action, but the one on the left shows a more closed frame. That is to say, the 
difference between the two images does not occur in its filming, but in their editing, becoming an element of cinematic thinking, revealing the fictional epistolary film as an essay film of the filmmaker's subjectivity. This sixth missive includes two more split screens, showing the sanctuary of Cham. The eighth letter begins with his account of the arrival in Da Nang and the visit to the Cham Museum. Then, the diegesis of epistolary fiction becomes problematic, as occurred in Sans Soleil, as it turns into a dialogue, no longer deferred, that transforms the epistolary device into the materialisation of an internal monologue. It establishes a dialectic relationship between female identity-linked to the filmmaker's first documentary work: personal space, portraiture, proximity- and the male one -the evolution towards the essay film, the notion of History, the distance. The dialectics begins in the female visual space to continue with that already shown in the male one -the split screen-, where both voices, both identities, the identity-alterity dialectics inherent to the human being meet. On this occasion, the split screen shows the same image, thus resolving the spatial and temporal decalages shown by the previous ones, accepting the filmmaker's identity split to turn this duality into a thinking tool of great relevance, which presents a crucial reflection on the female point of view. The identity conflict has been resolved and therefore the split screen disappears from the film. It is the assumption of that reality that enables both perspectives to materialise in a very fertile way in the following letters, to even reach the exchange in the twelfth, in which the male character comments on the images made by the female one. Nguyen addresses the gender perspective in the following letter, the thirteenth, in which she portrays two women together, expressing a bond between them that appeals to sorority (Figure 8):

I'm writing you from the land of the woman. Champa is a matriarchal society [...] the men, as usual, end up being the voice. The women here, like everywhere else, are like the background $[\ldots]$ They don't talk about the question or their survival $[\ldots]$ They are the landscape. 
Figure 8. Letters from Panduranga (2015, Nguyen Trinh Thi) Courtesy of the filmmaker

As May Adadol Ingawanij says, the film reaches 'a bringing into play of an aesthetics of matriarchal potentiality [...] images of the capacities of female bodies, female relationships and as matriarchal figures of deep time' $(2019,162)$. Thus, Nguyen exposes a reflection that also refers to the audiovisual creative space, where the female gaze still has to appropriate the intellectual space and its abstraction. It is precisely this evolution that Nguyen's film goes through. The last letter from her resumes the final words of Lettres de Sibérie on the images of women in a karaoke, dancing and singing. Thus, Marker's film acquires a new interpretation from a gender perspective, evidencing the work done by the film that concludes: 'I am writing to you from what seems like a distant land. Her name is Panduranga. She lies somewhere between the Middle Ages and the $21^{\text {st }}$ century, between the earth and the moon, between humiliation and happiness'.

Like The Dreamed Ones, Rita Azevedo Gomes' Correspondências (2016) is built through the epistolary exchange of two great authors, Jorge de Sena and Sophia de Mello Breyner Andresen, both crucial in $20^{\text {th }}$ century Portuguese Poetry. Their correspondence is caused by Sena's exile in 1959, first to Brazil and then to the United States, and lasts until his death in 1978. Like Beckermann, the filmmaker focuses on the epistolary reading/recitation. Besides, she merges the epistolary exchange and the poetic creation of both authors. From this textual duality, Azevedo builds an essay film through multiple hybridisations defining the complex image of contemporary cinema (Monterrubio 2020). Hybridisations among: reading, recitation and representation in several languages; real people and characters, creating a kaleidoscopic presence; voice-in and voice-over, generating a sort of abstract mental space of the same aesthetic experience; digital and analogue image in order to deautomatise their respective inertial interpretations regarding 
past reproduction and present representation; diegesis in front of the camera and extradiegesis consisting of the crew behind it; the essayistic $I$ and the cinematic $W e$. And, of course, between epistolarity and poetry. The epistolarity of the film, based on exile, as Hatoum's in Measures of Distance, is intrinsically linked to Naficy's analysis already mentioned. The poetic texts of both writers, on the other hand, emerge throughout the film without any specific mention to their authorships, revealing many of the poetic correspondences between both works. Azevedo hybridises epistolarity and poeticity, instrumentalising two possibilities of the essay film as analysed by Rascaroli. On the one hand, the epistolary essay film, in which epistolary becomes 'a disjunctive narrative form marked by distance and by absence' $(2017,20)$ which emerges from its interstitial nature. On the other hand, poetic essay film, in which: '[T]he lyrical in the essay film is not subordinate to logical thinking or separate from it $[\ldots]$ it is argument and instrument of argumentation' (157). That is, two opposed materials at the service of cinematic thinking: '[E]pistolarity and lyricism as examples of narration and counter-narration, both seen as disjunctive strategies that may be mobilized by the essay film to create a "form that thinks"” (163).

The film materialises a reflection on the aesthetic experience, instrumentalising all the audio-visual possibilities and creating a poetic-epistolary, sensory-emotional kaleidoscope around creation, exile and absence. About the inscription of the essayist self, two images define the complex image of epistolary contemporary cinema. The first one is the only image that will be repeated several times throughout the film. An analogue image of a garden, in which a swing oscillates, arises at the beginning of the film. In this first moment, it is inevitable to interpret it as a personal archive image, but its later repetitions showing different frames and camera positions move away its perception as an archive image to identify it with the authorial essayistic subjectivity, which repeatedly 
recorded it. A cinematic thinking of Azevedo's subjectivity is already created: that of the swing moving backwards and forwards, always in motion, on this occasion as a symbol of the poetic correspondences between Mello Breyner's and Sena's creations. The image reappears accompanied by Mello Breyner's voice, giving a definition of poetry:

Poetry asks to two contradictory things of people; one, to place ourselves in the void; and other, to place ourselves in communion. They are totally opposite things, and I think the character of a poem lies between the intensity of the void and the intensity of communion that one desires and needs. It is a play of contradictions.

The swing oscillating is then identified with the swinging that she describes between void and loneliness and the need for company. In minute 69 the digital image shows us that same space but without the presence of the swing, updating the analogue one. Three more appearances of this image confirm it as belonging to the author's reflective subjectivity, her thinking in action around the aesthetic experience the film proposes.

The second image of this subjective reflexivity arises at the end of the enunciation of Mello Breyner's letter of $31^{\text {st }}$ December 1967, in which she tells Sena about the deaths of her brother and her mother, occurred only a few months apart. The image hybridises the images of trees that traverses the film with that of Azevedo, who reads the text we have so far heard through the voiceover (Figure 9). This hybrid image exemplifies and synthesises the essayistic nature of the work and defines that complex image, kaleidoscope image, of contemporary cinema. The words Mello Breyner dedicated to her mother through the letter are now assumed by Azevedo, addressed through the cinematic work. The bond with the mother and the pain of her absence join the one imposed by exile and Azevedo identifies herself with Mello Breyner. The filmmaker thus gives her filmic answer, her reflection, to the question a little girl enunciates in the film and that Azevedo shared in her childhood: Where is the exile? This question undoubtedly prompts the 
search proposed by the film and also confirms the identification between the poetess and the filmmaker. Through Mello Breyner's and Sena's epistolary and poetic texts, it is Azevedo's subjectivity and thinking process which materialises in a contemporary essay film, a complex, filmic kaleidoscope, which becomes another avant-garde expression of epistolary essay film.

Figure 9. Correspondências (2016, Rita Azevedo Gomes). Courtesy of the filmmaker and C.R.I.M. Productions

\section{Conclusion}

This itinerary through epistolary films and epistolary essay films by women filmmakers allows to draw several conclusions. First, the relevance of the filmmakers in the innovation and evolution of epistolary enunciation is evidenced. Second, they use it truly fruitfully in order to explore not just alterity, paradigmatic concept of postmodernity inherent to the epistolary device, but female alterity. Thus, Akerman begins the epistolary film focusing it on the reception and reading space to explore an intimate alterity, that of the mother. Hatoum and Carri delve into that same experience in both visual perspective and personal experience. Ruivo, for his part, goes back a generation to make her grandmother that female alterity. Therefore, the epistolary film becomes a useful tool for the exploration of intimate female alterities. Its fictionalisation, based on documentary image, displaces the works from the intimate to the intellectual space. Stratman gives voice to a young university student in order to carry out an exercise of comedy, irony, criticism and even satire on many of the stereotype women must face. Green, for her part, generates an epistolary fiction where four women create a space of female intellectual intersubjectivity. In addition, women filmmakers resort to letters correspondence from other women, to once again carry out an exercise of feminist vindication and creative sorority. Lin performs an epistolary recreation exercise to get closer to the addresser's 
experience, that of captivity before execution, and to generate a political and social vindication for historical memory in her country. Beckermann uses the epistolary correspondence of two great writers to create an experience of epistolary reading and identification that, once again, takes sides in order to explore the female alterity of Ingeborg Bachmann as a woman both in the personal sphere -her relationship with Paul Celan- and in the artistic space -her lack of recognition as a writer. Finally, the creation of epistolary essay films again confirms the ability of women filmmakers to be at the avant-garde of this epistolary form. Nguyen materialises her cinematic thinking from an identity split that takes the form of a correspondence between a man and a woman. This reflection concludes with the need for women to gain visibility in the intellectual space, as many of the previous works already pointed out. Azevedo, like Beckermann, takes the correspondence of two other great literatures to create an essay film on the artistic experience and the exile, which cinematic thinking is also link to the identification with the feminine alterity. All these woman filmmakers explore the seriality and materiality of the epistolary device and the stratification of its audiovisual modality in order to show female alterities, whose exploration shows an evident progression from the intimate to the public, from the emotional to the intellectual, always as feminist vindication.

\section{References}

Altilio, Pilar. 2020. “Albertina Carri: la huella del horror hecha obra”. Clarín. Revista N. 19 abril 2020 https://www.clarin.com/revista-enie/arte/albertina-carri-huella-horrorhecha-obra 0 _ k3vZKoYx.html

Augé, Marc. 1992. Non-lieux. Introduction à une anthropologie de la surmodernité. Paris: Éditions du Seuil.

Barker, Jennifer M. 2003. "The feminine side of New York: travelogue, autobiography and architecture in 'News from home'." In Identity and memory. The Films of Chantal Akerman, edited by Gwendolyn Audrey Foster, 41-58. Illinois: Southern Illinois Univesity Press. 
Bauman, Zygmunt. 1991. Modernity and Ambivalence. Cambridge: Polity Press.

Boscarlo, Matteo. 2016. "Letter \#69" FilmFreeway

https://filmfreeway.com/Letternumber69

Bulher, José Michel, and Yves Laplace. 1977. “Locarno 77 : l'espace du leurre.” Cahiers du cinéma 281: 54.

Bluher, Dominique. 2019. "Varda's Gift of Postcards." Área Abierta. Revista de comunicación audiovisual y publicitaria 19 (3), 287-306.

https://dx.doi.org/10.5209/arab.62913

Carri, Albertina. 2015. Albertina Carri. Operación fracaso y el sonido recobrado. Dossier de la exposición.

Carri, Albertina. 2016. "El sonido recobrado". In Cine argentino contemporáneo: visiones y discursos, edited by Bernhard Chappuzeau and Christian von Tschilschke, 161172. Madrid: Iberoamericana Vervuert.

Dubroux, Danièle. 1977. “Il n’y aurait plus qu'une seule image.” Cahiers du cinéma 279280: 41 .

Gray, Ros. 2010. "Dreaming of Islands." In Endless Dreams and Time-Based Streams. Renée Green, edited by Betti-Sue Hertz, 24-32. San Francisco: Yerba Buena Center for the Arts.

Ingawanij, May Adadol. 2019. "Aesthetics of potentiality: Nguyen Trinh Thi's Essay Films." In Women Artists, Feminism and the Moving Image: Contexts and Practices, edited by Lucy Reynolds, 151-164. London: Bloomsbury Academic http://dx.doi.org/10.5040/9781350124295.ch-008

Kristeva, Julia. 1988. Étrangers à nous-mêmes. Paris: Librairie Artheme Fayard.

Lacan, Jacques. 1998. The Seminar of Jacques Lacan. Book 20. Encore. New York: Norton \& Company.

Le Feuvre, Lisa. 2010. "From Island Thought To Water Thought." In Endless Dreams and Time-Based Streams. Renée Green, edited by Betti-Sue Hertz, 16-23. San Francisco: Yerba Buena Center for the Arts.

Longfellow, Brenda. 1989. "Love letters to the mother: The work of Chantal Akerman." Canadian Journal of Political and Social Theory/Revue canadienne de théorie politique et sociale, Volume XIII, no.1-2: 73-90.

Margulies, Ivone. 1996. Nothing happens. Chantal Akerman's hiperrealist every day. London: Duke University Press. 
Marks, Laura. 2000. The Skin of the Film: Intercultural Cinema, Embodiment and the Senses, Durham: Duke UP.

Maupin, Françoise. 1977. "News from home.” La revue du cinéma 319: 109.

McFadden, Cybelle H. 2014. Gendered frames, embodied cameras: Varda, Akerman,

Cabrera, Calle and Mä̈wenn, Madison. New Jersey: Fairleigh Dickinson University Press.

Monterrubio Ibáñez, Lourdes. 2018. De un cine epistolar. La presencia de la misiva en el cine francés moderno y contemporáneo. Santander: Shangrila Ediciones.

Monterrubio Ibáñez, Lourdes. (ed.) 2019. La enunciación epistolar en el cine contemporáneo / Epistolary Enunciation in Contemporary Cinema. Monographic issue. Área Abierta, 19(3) https://revistas.ucm.es/index.php/ARAB/issue/view/3535

Monterrubio Ibáñez, Lourdes. 2020. “Correspondências by Rita Azevedo Gomes. The Complex Hybrid Image of Contemporary Epistolary Cinema and Contemporary Essay Film." Visual Studies 35(2):

http://dx.doi.org/10.1080/1472586X.2020.1771202

Naficy, Hamid. 2001. An Accented Cinema: Exilic and Diasporic Filmmaking. New Jersey: Princeton University Press.

Rascaroli, Laura. 2017. How the Essay Film Thinks. New York: Oxford University Press. Rascaroli, Laura; Nguyen Trinh Thi; Bo Wang; and Susana Barriga. 2019. "The Essay Film and its Global Contexts: Conversations on Forms and Practices." In World Cinema and The Essay Film. Transnational Perspectives on a Global Practice, edited by Brenda Hollweg and Igor Krstic, 21-35. Edinburg: Edinburg University Press.

Ricœur, Paul. 1990. Soi-même comme un autre. Paris: Éditions du Seuil. 